\title{
Strategy Analysis of the Biggest World Supermarkets With Open Capital and Which Act in the Brazilian Market
}

\author{
Thyago de Melo Duarte Borges, João Agra Neto, Luciano Queiroz de Araújo Júnior \\ Universidade Federal do Rio Grande do Norte (UFRN), Natal, Brazil \\ Jamerson Viegas Queiroz, Fernanda Cristina Barbosa Queiroz, Faimara do Rocio Strauh, \\ Nilton Cesar Lima, Christian Luiz da Silva \\ Universidade Tecnológica Federal do Paraná (UTFPR), Curitiba, Brazil
}

\begin{abstract}
In view of the growth of retail, as well as the performance of large multinational supermarket branch in the Brazilian market, the purpose of this article is an analysis of the strategies of Casino, Carrefour, Walmart and open in the country capital, analyzing their operational, financial indicators socio-environmental initiatives. In order to achieve the main objective of this work, the construction of a method that validates this search was necessary. The main strategies and indicators of the three groups in four areas: corporate strategy, operational areo, financial areo, social and environmental issue, were analyzed. Study of qualitative, descriptive and exploratory character is realised through the importance of these three companies worldwide. As conclusions, it has been the expansion strategies that geared toward developing countries, adherence to new store formats, specializing in electronic commerce, as well as the superiority of Walmart (net sales) and Casino (Profitability).
\end{abstract}

Keywords: Strategy, Supermarkets, Wal-Mart, Carrefour, Casino

\section{Introduction}

Despite the global economy being passed by a crisis, consumers are still spending, and one of the sectors that benefit from this is retail. Supporting this claim, according to studies carried out by the consultant Deloitte

Thyago de Melo Duarte Borges, M.Sc. student in Production Engineering, Universidade Federal do Rio Grande do Norte (UFRN), Natal, Brazil; professor of Production Engineering Department, UFERSA.

João Agra Neto, M.Sc. student in Production Engineering, professor of Production Engineering Department, Universidade Federal do Rio Grande do Norte (UFRN), Natal, Brazil.

Luciano Queiroz de Araújo Júnior, M.Sc. student in Production engineering, professor of Production Engineering Department, Universidade Federal do Rio Grande do Norte (UFRN), Natal, Brazil.

Jamerson Viegas Queiroz, Ph.D., professor of Production Engineering Department, Universidade Tecnológica Federal do Paraná (UTFPR), Curitiba, Brazil.

Fernanda Cristina Barbosa Pereira Queiroz, Ph.D., professor of Production Engineering Department, Universidade Tecnológica Federal do Paraná (UTFPR), Curitiba, Brazil.

Nilton Cesar Lima, Ph.D., professor of Management Department, Universidade Tecnológica Federal do Paraná (UTFPR), Curitiba, Brazil.

Faimara do Rocio Strauh, Doctor in Production Engenireering, professor of Production Engineering Department, Universidade Tecnológica Federal do Paraná (UTFPR), Curitiba, Brazil.

Christian Luiz da Silva, Doctor in Production Engineering, professor of the Departament of Economy, Universidade Tecnológica Federal do Paraná (UTFPR), Curitiba, Brazil.

Correspondence concerning this article should be addressed to Thyago de Melo Duarte Borges, Production Engineering Department, Universidade Federal do Rio Grande do Norte (UFRN), Natal, Brazil. E-mail: tmdborges@ gmail.com. 
(2013), weighted and adjusted revenue of 250 largest retailers' sales increased in the year 2011 at $5.1 \%$, and more than $80 \%$ of the 250 reported an increase in revenue. Among these retailer is the action of the supermarket groups.

According to Parisotto (2005, p. 23) "Supermarket sector is different from the industry, because it is the point where the product is closer to the consumer, and therefore, where you can check more quickly the levels of satisfaction and quality of a product". According to the Brazilian supermarket Association (ABRAS), although the contents of supermarket sales have not been satisfactory in 2012 compared to previous years, mainly the year of 2010 in which the growth in revenue was $5.1 \%$ and $6.7 \%$ in values, it is estimated that by the end of 2013 its revenue is 314 billion, thus achieving a jump of $26.1 \%$.

As the rise of Brazilian groups, there is competition from multinationals. Among the companies that have entered the domestic market, Carrefour, the French network came to Brazil in 1975, and the first group of foreign supermarkets arrived in the country.

Also there highlights the Walmart group. Pinto (2007), citing in BID (1997), said that Wal-Mart's arrival in Brazil in the early 1990s triggered profound transformations that directly influenced the setting and the dynamism of the Brazilian supermarket sector. Another organization that influences the economy of the sector in the country is the Casino Group, which acquired the Brazilian company Pão de Açúcar. According to Gpari (2013), this transaction occurred on July 2, 2012, when the Casino acquired the majority stake of the control group, becoming senior partner.

According to the ranking of Deloitte Consulting, which lists the most powerful 250 global retailers, Wal-Mart, Carrefour, Casino are among the top 34. The Wal-Mart group is the largest group of retails of world stage, followed by the Carrefour group, the Casino Group in 22nd place. On the scenario above, the main objective of this work is to analyze the strategies of the largest publicly traded world and supermarkets operating in the Brazilian market.

From this goal, a description of the specific objectives is to check one of the biggest global retailers, which are the world's supermarkets that have publicly traded on a stock exchange and act in the Brazilian market; carry out a survey of the actions of three supermarkets in respects their strategies; analyze your operational indicators, environmental initiatives, and financial indicators; and, from the analysis of the previous goal, assess the strategies developed by supermarkets. In this way, in view of the importance that the supermarket sector represents for the country and for the world market, it is appropriate for this study regarding the influence of these three groups (Walmart, Carrefour, and Casino) in global retail economy, since they are the largest retailers publicly trade with Brazil and active in the Brazilian market.

The first section of the article introduced the subject, explaining the main objective, as well as the background of the work. The second section discusses the concepts of competitive managerial strategy, service industry and supermarkets in more detail, providing an overview of previous studies that have addressed the issue. The third section describes the methodological aspects of research. The fourth, the case studies of each organization, listing their actions, indicators and initiatives in each area explained in objectives. The fifth section concludes the work, addressing the main results.

\section{Managing Competitive Strategy}

The management of an organization's competitive strategy is one of the most effective tools for generation of wealth of a company (Luppe, 2010). Venkatraman and Henderson (1998) argued that the strategy should have an 
objective definition, whereby they stated that this is an interactive process of recognition in order to develop and adjust the competitive advantage of a company through dedication and commitment. Porter (2004) complemented to know that the relationship between company and environment is the key to formulate a competitive strategy.

In the vision of Marques and Noronha (2001), in the formulation of a strategy it is necessary to have knowledge about the goals you want to achieve. According to Carneval and De Dreu (2006), since the beginning of research in negotiation, they have considered the goals and reasons of a strategy as a key element of the negotiations. Studies of Keck and Samp (2007), Liu and Wilson (2011), and Wilson and Putnam (1990), examined how the negotiation goals influenced attitudes or behaviors of elements in a supply chain. In order to understand the process of functioning of strategies, it is necessary to clarify the concept of core competencies, as well as the way these aggregates maintain a consolidation strategy. Hitt, Ireland, and Hoskisson (2003) discussed some tools that assist in identifying skills, which are valuable capacity, rare capacity, expensive imitation, irreplaceable capability, value chain analysis.

\section{Retail Strategies}

After a brief review of the concept of strategy, addressing both classic views as some recent aspects on the subject, this session aims to report some strategies used by the retail industry.

According to the vision of Danese, Romano, and Formentini (2013), one of the most relevant strategies in the retail industry consists of integrating your supply chain and several companies are rethinking their strategies at the expense of your supply chain. Several surveys address this issue, for example, Squire, Cousins, Lawson, and Brown (2009) reported on the cooperation within the chain; Fiala (2005) discussed the data and information management; and Gibbon, Bair, and Ponte (2008) researched about the development of new products and processes, as well as new investments from the integration of actors in the chain.

In the view of Danese et al. (2013) this integration between partners provides a reduction in production costs, and at the same time ensures better service to consumers, and this interaction has produced significant changes in participating companies.

As the integration between the participating companies of the supply chain has been a viable strategy for the retail sector, it is claimed that this also makes use of a fairly common tactic among organizations, the practice of Benchmarking. For Bolton and Shankar (2003) this strategy has been a source of interest of scholars such as the market, considering that it evaluates and analyzes the factors that cause the generation of sales volume.

Ratchford (1982) argued that the trend of the studies in this area consists in the evaluation of productivity of specific stores which will serve as a comparison to other stores, and whether competition or organization, the initiative also causes the development of marketing strategies.

Another strategy that deserves to be quoted in this reference is in the money, also called the financial slack that many retail companies are looking to get. For Nohria and Gulati (1996) and Kim and Huarng (2011), this strategy is considered to be a kind of innovation. More recent studies such as Baker and Nelson (2005) and Mishina, Pollock, and Porac (2004) claim that the excess resources are also considered as a financial slack, in which this is only used when the retailer's performance begins to fall.

About innovation strategies of retail industry, the research of Hauser, Tellis, and Griffin (2006) shows that measures of innovation performance, including new products, new processes and modifications can result in best practices, developing a competitive strategy. In the view of Woodside, Ko, and Huan (2012), the current 
competitive landscape which retail companies are entered requires an extreme emphasis on price, quality and customer satisfaction, demanding a greater recognition of innovation as a strategic competence.

\section{Supermarkets}

According to the Brazilian Association of Supermarkets (ABRAS), supermarket is food retailers that use the self-service system, featuring two or more check-outs and four basic areas: perishable, grocery, household cleaners and drinks. In the vision of Mishina et al. (2004), the supermarket format only gained momentum after World War II in the United States, and its growth is slow.

According to Nielsen Company (2011), although the industry has declined in recent years, this still is considered as the largest sales channel of wide consumption products and high turnover, accounting for more than $60 \%$ of sales in value of everything that is sold to the final consumer. Some modifications in the supermarket have been observed, such as the tendency of increase of the assortment of products (Nielsen Company, 2011), thus increasing the challenge of keeping proper and profitable products, but this product hyper segmentation may involve negative consequences for the consumer (Schawartz, 2000; Chernev, 2003; Mogilner, Rudnick, \& Iyengar, 2008).

After more than five decades of deployment in the country, the supermarket has become an important element in the way of life of the population and of their concerns as a consumer. In the decade of 1960 and later, the main supermarkets were installed in Brazil, including the sedimentation of large chains, inaugurating the opening of the first hypermarkets in the 1970s (Marques \& Noronha, 2001).

In the transition from 1990s to 2000s, foreign groups incorporated several national networks, but also there was acquisition of small and mid-sized networks by major national networks, resulting in a structural change of the market, with the largest concentrations in this area of retail (Ghisi, De Camargo, \& Martinelli, 2003).

In supermarkets there is a heated market, because Brazil's economy is allowing a quick resumption of growth, thus causing the increase of jobs, increased consumer confidence indexes, interest following downward trend, inflation under control and foreign growth in productive sectors (Brazilian Institute of Geography and Statistics, 2011; Nielsen Company, 2011)

This allows the Brazilian class C to consume products that used to consume. Luppe (2010) corroborated this statement when addressing that consumption growth of categories, such as beverages, soy based ready tomatoes and yogurt sauce is being used more frequently by socioeconomic levels C, D, and E, so they purchase for the most noble products. This same author asserted that these classes have contributed to more than $80 \%$ of the increase in consumption of these product families.

\section{Social-Environmental Action}

From the relevance that the theme of sustainability is gaining in recent times, highlighting the environmental and social aspects, it is interesting to discuss the initiatives of companies in relation to this theme.

According to the definition of the European Comission (2011), sustainability in a business perspective is seen as the concern of these companies with the impact on environmental and social terms, as well as a way to interact with its stakeholders. According to Abramovay (2010) there is no other alternative for organizations to adhere to sustainability, and in the future only companies with sustainable goals will achieve the competitive advantage.

There are many explanations for the commitment of these companies, such as: be socially responsible to 
assist in business sustainability, credit gain on transactions with the Government; be proactive in this area better than be reactive, especially with regard to stakeholder vision (Carroll \& Shabana, 2010).

However, for this involvement the organization must adapt to a management that promotes sustainability. Confirming this sentence, Doppelt (2010) stated that for an organizational change, for the insertion of sustainability as a management concept, you must implement a cultural change. In this same approach, Veiga (2010) reported sustainability as a new value, a new social context, requiring companies' greater understanding and involvement of people.

In this context, it is important that all stakeholders perceive that the company is directing some of their actions in terms of sustainability, it is important that the organization develops and measures their actions from the perceptions of stakeholders (Calabrese \& Scoglio, 2012; Calabrese, Costa, Menichini, \& Rosati, 2013; Costa \& Menichini, 2013). The results from investment in sustainability (such as company reputation, more customers, and loyalty of employees), depend exclusively on the perceptions of stakeholders (Knox \& Maklan, 2004; Calabrese et al., 2013).

\section{Methodological Procedures}

In order to achieve the main objective of this work, the construction of a method was necessary to validate this search. For this purpose, the main strategies and indicators of the three groups in studies, Carrefour, Walmart, and Casino, will be analyzed. These items will be discussed in four areas: corporate strategy, operational area, financial area, social and environmental issue.

In the area of corporate strategy, the expansion strategies of each company will be analyzed. In the operational area, the indicators total number of shops (shop added with stores acquired from other organizations) will be outlined, as well as net sales of companies compared for the years 2011 and 2012. Then, the financial gains of each organization in terms of profit and return on investment are evaluated in the financial area.

To complete the comparison of the strategies of these organizations it is important to include indicators and placements that address the environmental and social issue. Environmental programs focuses on related issues such as: the attempt of reducing the emission of polluting gases, initiatives that involve recycling, and reducing electricity consumption. As regards social issue, strategies that deal with themes related to the following issues: overall responsibility, local community support, workers with disabilities, employee training, combat discrimination, and the number of women in charge of management.

All the strategies and indicators that will be inserted and analyzed for this article were taken from the following reports:

Carrefour: Carrefour Financial Report 2012 (Retrieved from http://www.ecobook.eu/carrefour/2013/ dr2012en/DREN-2012.pdf), 2012 Annual Activity and Responsible Commitment Report (Retrieved from http://www.carrefour.com/sites/default/files/Carrefour_RA_GBlight.pdf), and 2011 Annual Activity and Responsible Commitment Report (Retrieved from http://www.carrefour.com/sites/default/files/RADDEN 2011.pdf);

Casino: 2012 Annual and Corporate Social Responsibility Performance Report (Retrieved from http://www.groupe-casino.fr/en/Download-the-2012-Annual.html), 2011 Annual and Corporate Social Responsibility Performance (Retrieved from http://www.groupecasino.fr/IMG/pdf/RA2011-EN.pdf), and Report Casino 2012 Registration Document (Retrieved from http://www.groupecasino.fr/IMG/pdf/ Casino_2012_ Registration_Document.pdf); 
Walmart: Walmart 2012 Annual Report (Retrieved from http://www.walmartstores.com/sites/ annual-report /2012/WalMart_AR.pdf) and Walmart 2011 Annual Report (Retrieved from http://www. walmartstores.com/sites/annualreport/2011/);

All these indicators and strategies are definited, and a comparative analysis of the three business groups will be carried out, for understanding how to outline the strategies of each organization. This research is characterized as qualitative, descriptive, and exploratory character, considering that it analyzes the strategies of three case studies, namely, explores, describes, and interprets the three supermarket companies' initiatives in terms of their strategies.

\section{Data Analysis}

\section{Strategical Indicators}

This session aims to discuss the main guidelines of the supermarkets in the study with regard to their corporate strategies.

From the analysis of the 2012 Annual Activity and Responsible Commitment report (Retrieved from http://www.carrefour.com/sites/default/files/Carrefour_RA_GBlight.pdf), Carrefour has been expanding its business around the world, mainly with regard to restructuring of local partnerships, providing greater responsibility and freedom for the managers of each country, this fact is proven in countries such as Greece and Indonesia, i.e. through the establishment of franchises. According to the same report, this change in strategy has provided a greater ability to invest in other markets, such as France and development operations in China and Brazil, which are configured as strategic points.

While countries like China and Brazil deserve greater emphasis by the company, Colombia was a market that had its assets sold by the organization. To justify this fact, Carrefour said that these assets were less than market share.

Even in this discussion of General strategies, Carrefour has established some strategic priorities which should be established, such as:

- Reinvest in the assets, not occurred in Colombia;

- Modernize the stores, improve the parking lots, and commercial galleries;

- Continue to expand in all countries, especially in key countries, Brazil and China;

- Decentralize and streamline the business, that is, to give greater support to local initiative, giving store managers more autonomy and responsibility, if the previously mentioned franchises;

- Strategy of low prices on the products of daily life;

- Return of the fresh product up to 72 hours;

Another strategy adopted by the company, although not included in their priorities, is the investment in convenience stores. According to data from the organization itself, only 559 were installed in this format stores in 2012. The Table 1 demonstrates how much the company has invested in this format.

It is also the strategy of the organization vis-à-vis and commerce investments, i.e. in the perception of the company to the customer's needs for electronic purchases. To address this fact, Carrefour launched a mobile application in France called Carrefour MonPanier Cit, in which you can make your purchase via the device and find their products in a special box in the store.

The investment trend is also strong in non-food products and partnerships with major national banks, Itau-Unibanco in Brazil and Sun Bank in Taiwan, emphasizing the creation of Carrefour in France. 
Table 1

Number of Stores by Shape

\begin{tabular}{ll}
\hline Shape of store & Quantity \\
\hline Hypermarkets & 1,366 \\
Supermarkets & 3,454 \\
Convenience & 5,010 \\
Cash and carry & 164 \\
\hline
\end{tabular}

Note. Source: Data taken from the annual repost of 2012 of the company Carrefour.

Casino Group. As seen in the case of Carrefour, the Casino Group also has invested in their stores around the world, evidenced by the controlling interest of the Brazilian group in the year of 2012, by the agreement signed with the Geleries Lafayette, thus acquiring 50\% of the French company Monoprix.

The company has expanded its business in Colombia, while Carrefour has stopped investing in that country, and in Uruguay, as well as in Vietnam (big C). The Group justifies such an investment in increased purchasing power of the middle class in these countries, therefore, banners already are known in the country.

Brands such as Sendas and Extra in Brazil have been adapted to reach certain markets, while the Extra aims to reach a clientele looking for basic products, the path to the upper middle class. According to the company, the Casino is leading sales in Brazil (as a result of food and non-food) and stands in second place in terms of e-commerce.

This country has received major investments of the group, in which brands like Casas Bahia and Ponto Frio are parts of the Casino, demarcating the presence of non-food company. The Table 2 represents both the commercial profit as the Casino Group's foreign sales are concentrated in Latin America, most of which are from Brazil.

Table 2

External Purchases and Commercial Profit by Region

\begin{tabular}{|c|c|c|c|c|c|c|c|}
\hline \multirow[b]{2}{*}{ In millions } & \multicolumn{3}{|c|}{ France } & \multicolumn{3}{|c|}{ International } & \multirow[b]{2}{*}{2012} \\
\hline & Casino frança & Monoprix & Franprix-leaderprice & Latin America & Asia & Other international business & \\
\hline $\begin{array}{l}\text { External } \\
\text { purchases }\end{array}$ & 12,158 & 2,010 & 4,279 & 19,251 & 3,407 & 866 & 41,971 \\
\hline $\begin{array}{l}\text { Commerce } \\
\text { profit }\end{array}$ & 400 & 122 & 163 & 1,060 & 241 & 16 & 2,002 \\
\hline
\end{tabular}

Note. Source: Data taken from the annual report of 2012 of the company.

As well as Carrefour, Casino Group also operates in more than one aspect of retail, including the cash, electronic and specialized retail and carry. The company also has invested in other store formats, according to the organization, more dynamic, as in the case of convenience stores and discount stores. The investments should be noted also in e-commerce and franchise openings, since 2010 the company has signed more than 400 contracts in this format. Another strategy in the organization was the strong reduction of prices at the end of the year 2012 for the private label Casino. This demonstrates the intention of the company to focus on its grounds as retailer through ambitious price cuts in hypermarkets, and focuses on managing their costs.

Walmart. As seen in the case study of Carrefour and Casino, Walmart also has as a strategy of the growth of their business outside the United States, this fact can be explained by the addition of 52.2 million square meters from 1,160 additional units, including acquisitions in the United Kingdom and South Africa. 
China and Brazil also constitute a priority for the company, as main strategy increased financial returns, for this, Walmart has been enhancing productivity and reducing costs, and establishing a focus on the middle-class market of these countries, taking into account the purchasing power of this portion of the population.

As an example, the company has plans to invest $51 \%$ of the shares in Yihaodian, a Chinese website of expressive growth. Also considered as relevant strategies of the company's strong return to shareholders through dividends and buybacks during the year, according to the company's data, this return came to 11.3 billion dollars in the year of 2012, while the Casino, Walmart began a strong campaign for price reduction, establishing a priority as the reduction of costs and improvement of productivity. Walmart sets out five key strategies, which are to:

- develop employees, from programs like Business Leadership Series and the Walton Institute;

- lower costs to lower prices and seek the leadership in the areas of supply, information system, business processes and shared services;

- lead electronic commerce;

- reinvigorate the culture of customer focus from studies of customer buying behavior;

- lead in socio-environmental issues through the good relationship with governments and non-governmental organizations (NGOs);

\section{Optional Indicators}

After a brief analysis about the main strategies of the three companies in question it will be addressed the main indicators of these organizations with respect to the operational area. Two indicators were chosen: comparison of net sales of the 2011 and 2012 number of shops that each company has until 2012 (indicators for 2013 were not consolidated by the end of this study). The first analyzed indicator consists of the comparison of net sales of 2011 and 2012. It should be noted that these data are for all business units around the world. The Table 3 represents such a comparison.

Table 3

Comparison Between the Net Sales of the Year of 2011 and 2012 in American Dollars

\begin{tabular}{llll}
\hline Company & Net sales 2012 & Net sales 2011 & Growth \\
\hline Carrefour & $102,620,819.60$ & $108,610,564.40$ & $-5,989,744.80$ \\
Casino & $56,128,800$ & $45,437,600$ & $10,691,200$ \\
Walmart & $443,900,000$ & $419,000,000$ & $24,900,000$ \\
\hline
\end{tabular}

Note. Source: Data taken from the annual financial reports of each organization.

From the analysis of the data it showed that the company Walmart was the organization that obtained the greatest growth of its net sales, that is, an increase of 24.9 million dollars; the Casino Group has obtained an increase of 10.6 million and the Carrefour closed the fiscal year 2012 in prejudice towards 2011. After analysis of net sales hall to be assessed, the number of these companies have stores around the world. These data (number of companies) are represented in the Table 4.

From the resulting data, the Casino Group has the largest number of stores around the world, followed by the Carrefour and Walmart. It is interesting to note that despite the Walmart having the smallest number of stores, this company had the largest net sales of its products, that is, its differential is not based on quantity, although this group also owns the expansion strategy. 
Table 4

Number of Stores Around the World

\begin{tabular}{lll}
\hline Company & Number of stores (own + acquired) & Number of countries where the company works \\
\hline Carrefour & 9,994 units & 33 \\
Casino & 12,000 units & 08 \\
Walmart & 1,094 units & 15 \\
\hline
\end{tabular}

Note. Source: Data taken from the annual reports of the companies.

\section{Social Initiatives}

This section has to address the main initiatives of the companies in the study with respect to their environmental and social oriented actions, it is understood that this kind of activity is also a way to attract more market for each organization as the issue of sustainability is guided in the world.

Carrefour. Carrefour has invested their efforts in some actions that promote innovation in the logistics chain, as the warehouse, a combination of share modes (road, rail, and inland waterway), as well as testing with the biomethane fuel produced from the waste generated by the supermarkets, in their trucks.

Another initiative is to make the units of the company more sustainable, using the rule of technologies that promote the use of more sustainable energy as a main goal. It should be noted that in some French units the company has been adopting the model of green building through a letter that limits the impacts caused by the store environment.

In suppliers, Carrefour has 26,000 ISO certification, as function evaluates them with respect to their environmental impacts. A set of 40 questions are held by every supplier in order to analyze what environmental management is.

By the year 2012, a total of 6240 suppliers have been assessed, also the programs of humanitarian aid to victims of natural and industrial disasters.

Casino. The Casino Group, as well as Carrefour, also has initiatives that aim to reduce impact on the environment. City Green program aims to decrease carbon gas emission during product delivery by the company. Already the Green Yellow encourages the company's units to use energy from the sun and some stores already use cards that capture solar energy, which are present only in France.

Green Cycle is a project that encourages the recycling of the company's products and customers are encouraged to return the packaging company collecting stations if they are to be recycled.

The ecofriendly project is an initiative of the Brazilian units, where the shops are encouraged to reduce water and energy consumption. It should be noted also that the hat combats discrimination against minorities in business, makes the foundation for assistance to needy children, and provides education and personal and intellectual development.

Walmart. The big company marketing creation of the subject in question is the Walmart considered by Green Power Partnership (EPA) as the largest green company of the United States. Justifying such a title, the company has some programs such as the reduction of emission of gases within the supply chains, projects that stimulate sustainable agriculture among its suppliers, as well as $21 \%$ of the electricity used by the company coming from renewable sources. Walmart says that good relationship with governments and NGOs provides the creation and joining projects that encourage sustainability.

In social terms, the company claims to have donated more than 1 million dollars in kind only in the year 
2012 to institutions, being the total (international and United States) reaching the figure of 311 million, 1 billion meals to needy families, through their donation of food banks.

With regard to its employees, the company has increased almost 1 million job opportunities for women, constituting a framework for $28 \%$ of the employees of this genre. This initiative is the result of a program called Global Women's Empowerment, and according to the company, more than 300,000 employees work in it for more than 10 years.

Financial Indicators. Finalized the analysis of socio-environmental aero, operational aero and strategy, some financial indicators have been raised, and such indicators were removed from the financial statements of each company. To better understand about the parsed data in the session of operational indicators, Table 5 will analyze the profitability of companies, whether it is financial or economic. Table 5 represents this profitability.

Table 5

Calculation of Profitability

\begin{tabular}{lllllll}
\hline \multicolumn{2}{l}{$\begin{array}{l}\text { Data in millions of dollars for the rentability calculation } \\
\text { Data }\end{array}$} & \multicolumn{3}{c}{ Wallmart } & \multicolumn{3}{c}{ Carrefour } & \multicolumn{2}{c}{ Casino } \\
\cline { 2 - 7 } (bills) & 2011 & 2012 & 2011 & 2012 & 2011 & 2012 \\
\hline Net result & 25.542 & 26.558 & 0.534 & 1.739 & 0.9806 & 2.026 \\
Net result + financial wastes & 25.542 & 26.558 & 0.534 & 1.739 & 0.9806 & 2.026 \\
Net selling recipe & 418.952 & 443.854 & 100.530 & 101.484 & 45.4115 & 55.46887 \\
Net patrimony & 71.254 & 75.761 & 10.0798 & 11.0498 & 20.0896 & 12.4006 \\
Passive total & 109.535 & 117.645 & 63.3456 & 60.5874 & 39.3467 & 56.5817 \\
\hline
\end{tabular}

Note. Source: data taken from the financial reports of each company.

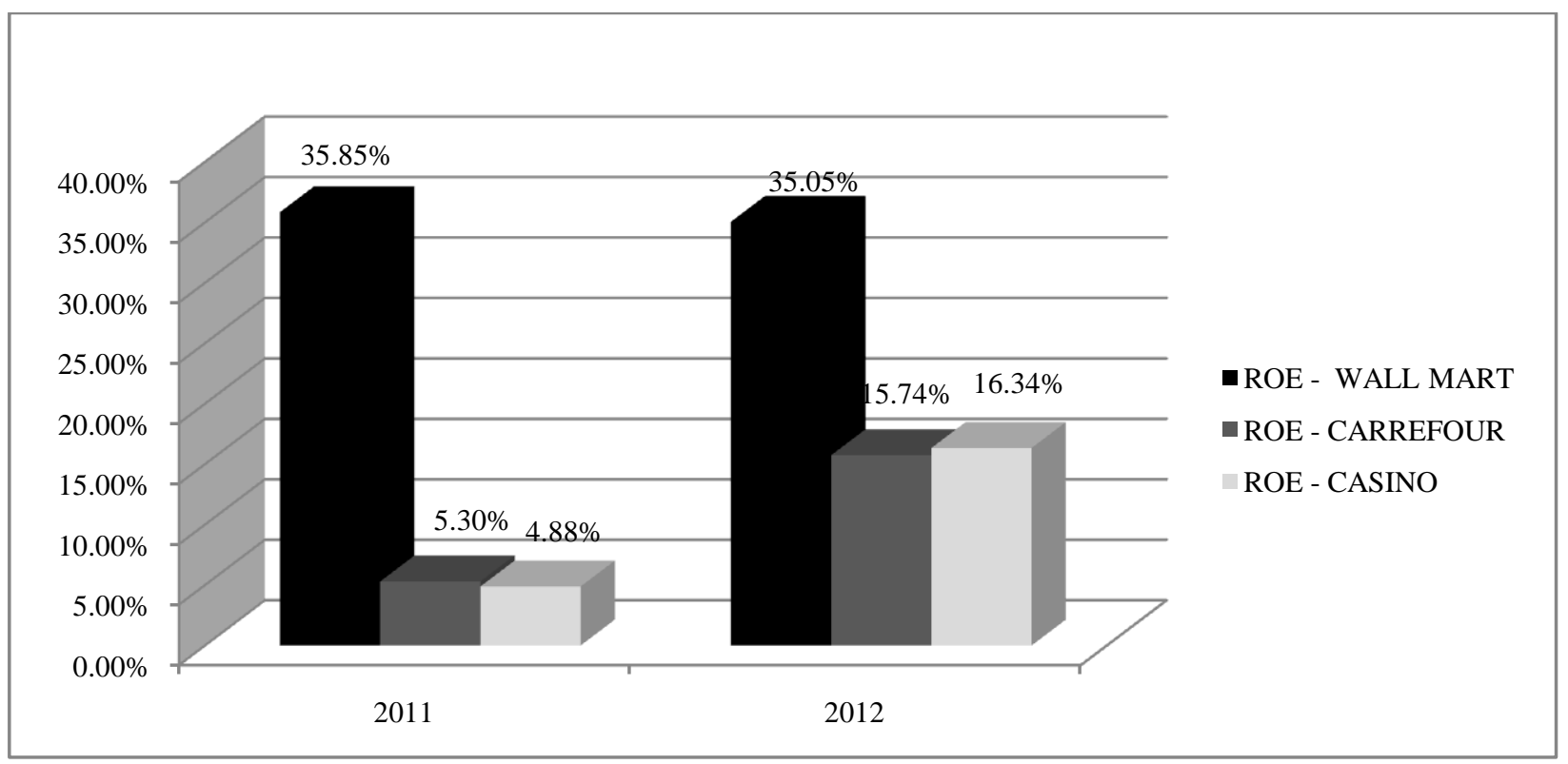

Figure 1. Financial rentability.

Figure 1 shows graphically how the return on investment of each company is analyzed in the article and the superiority of Wallmart in relation to its competitors.

In two indicators of profitability, financial and economic, the Wallmart obtained advantage. On financial profitability, the Carrefour was higher than the Casino Group in 2011 and 2012, although lower than in 
economic profitability, the Carrefour group was superior to Casino in both years 2011 and 2012. Analyzing the net sales revenue and the profits of the groups, the Wallmart has increased its revenue by $\$ 24,902$ million ( $\$ 418,952$ million dollars in 2011 up to $\$ 443,854$ million dollars in 2012) and this is reflected in an increase in profits of $\$ 1,016$ million dollars ( $\$ 25,542$ million in 2011 up to $\$ 26,558$ million in 2012). Such information falls in profitability percentage both in economic and financial aero, since it requires a large volume increase of net sales revenue for a small increase, when compared with the value of sales revenue, profitability.

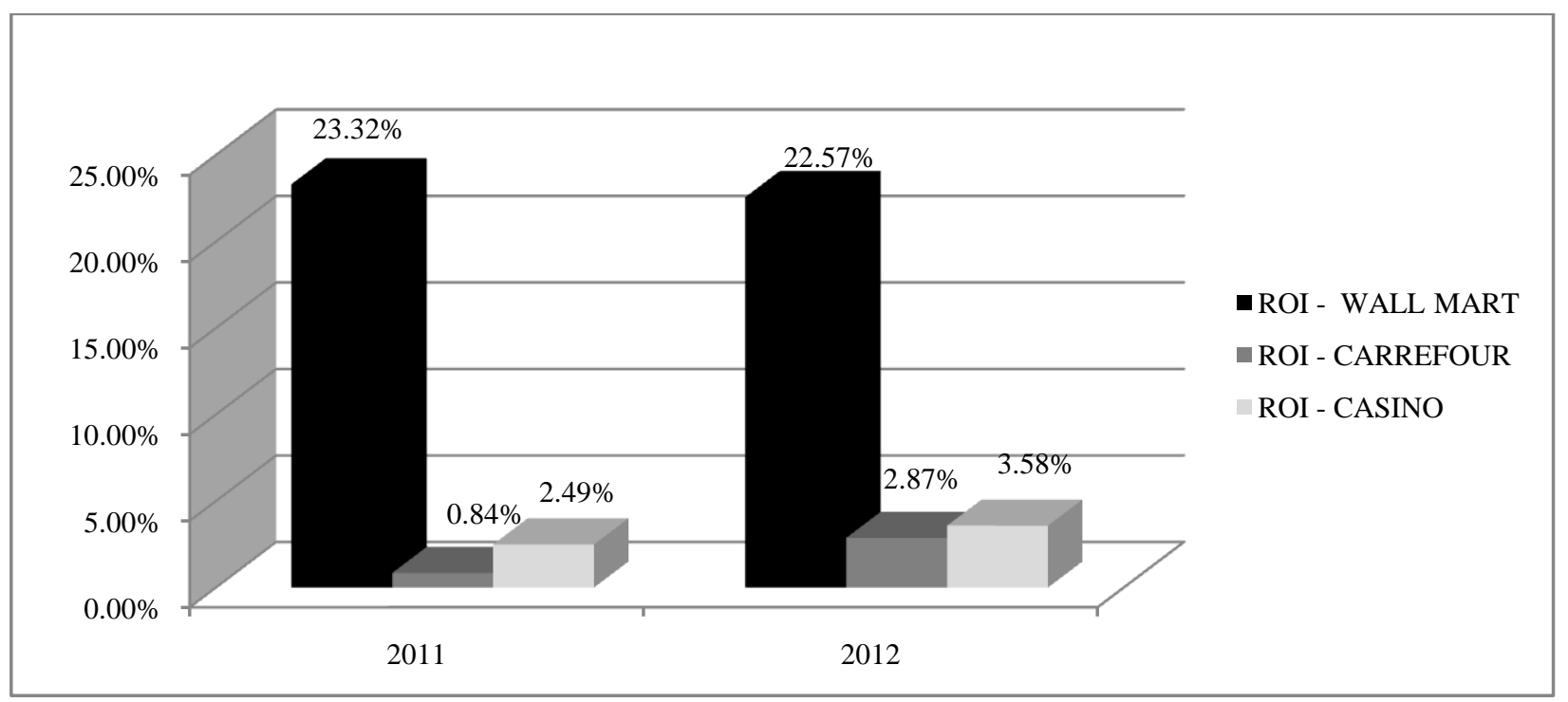

Figure 2. Economic rent ability.

The Carrefour had superior performance to Wallmart in terms of percentage increase of profitability, since the same increasing your net revenue of the sale by a small value of $\$ 0.95419$ million $(\$ 100.530$ million in 2011 to $\$ 101.484$ million in 2012), this company achieved a significant increase in the value of profitability, equal to $\$ 1.20529$ million ( $\$ 0.5339$ million in 2011 to $\$ 1.7392$ million in 2012).

The Casino had the best performance among the three, since it almost quadrupled its percentage increase in financial profitability (ROE). But not getting the same success in increasing economic profitability (ROI), with an increase of almost $1.5 \%$ percentage, the Casino Group stands out due to the fact of having achieved more than triple year of profitability in 2012 in relation to 2011, and its profitability grew $\$ 1.04538$ million (\$0.9806 million dollars in 2011 to $\$ 2.0260$ million dollars in 2012).

\section{Conclusions}

From the four areas established for the analysis of strategies of enterprises, and in accordance with the goals set, which is to analyze the strategies of the three companies, analyze your operational and financial indicators, as well as perform an analysis regarding their environmental actions, some conclusions can be drawn up. In that match to the strategies of expansion of organizations, one realizes that the three companies have similar guidelines, i.e. they are encouraging investment in emerging countries, including Brazil and China, and the main justification for such investment is the growing power of middle-class shopping of those nations.

Another inherent strategy consists of investments in franchises, in convenience stores and e-commerce. In this perspective, there is investment in the franchise by Casino and Carrefour, according to research of this 
article, there is no evidence found in the reports of Walmart indicating a trend that has this type of investment. So, it could be considered that this is not a focus of the Walmart group strategy, as well as not focus investment in convenience stores.

From the analysis of operational data, the advantage that Walmart has to the others was realized, and this fact justified by its net sales exceeds the competition. It's up to reflection about how the strategy of the company has been successfully established, because despite having a smaller number of stores and that it could not invest, as competition has been invested in franchise formats and convenience stores, this organization follows the absolute leader in the retail industry. One of the justifications may be based on strong company policy on cutting the cost of its operations, so there is a fall in prices of its products.

However, in the case of financial indicators from the financial and economic return on investment, the Casino Group, in view of the profitability of the company, surpasses the others. This fact can be justified by the investment strategy in markets such as Brazil, and the lowering of prices adopted by the company policy.

In order to match the environmental initiatives, it is noted that companies in the study have sought to demonstrate how to reduce their social and environmental impacts. Promoting projects aimed at the reduction of the emission of pollutant gases, use of renewable energy, or even the decrease in consumption of electricity. This kind of initiative needs to be addressed by the organizations because the level of knowledge of the environmental themes of their customers has grown.

It is considered that the objectives established by this article have been met - the strategies of the three companies were raised and analyzed in a study in which it consists of the expansion strategies, operational and financial indicators, as well as with social and environmental initiatives. It indicates a future research with a better development of financial indicators, in view of the great importance that these groups provide in terms of data analysis strategies.

\section{References}

Abramovay, R. O. (2010). Environmental discourse remain precarious until we develop a more refined understanding of what the market is. What economists think about sustainability, 34, 265-281.

Baker, T., \& Nelson, R. E. (2005). Creating something from nothing: Resource construction through entrepreneurial bricolage. Administrative Science Quarterly, 50, 329-366.

Bolton, R. N., \& Shankar, V. (2003). An empirically driven taxonomy of retailer pricing and promotion strategies. Journal of Retailing, 79(4), 213-224.

Calabrese, A., \& Scoglio, F. (2012). Reframing the past: A new approach in service quality assessment. Total Quality Management \& Business Excellence, 23(11-12), 1329-1343.

Calabrese, A., Costa, R., Menichini, T., \& Rosati, F. (2013). Does corporate social responsibility hit the mark? A stakeholder oriented methodology for CSR assessment. Knowledge and Process Management, 20(2), 77-89.

Carnevale, P. J. D., \& De Dreu, C. K. W. (2006). Motive: The negotiator's raison d'être. In L. L. Thompson (Ed.), Frontiers of social psychology: Negotiation theory and research (pp. 55-76). New York: Psychology Press.

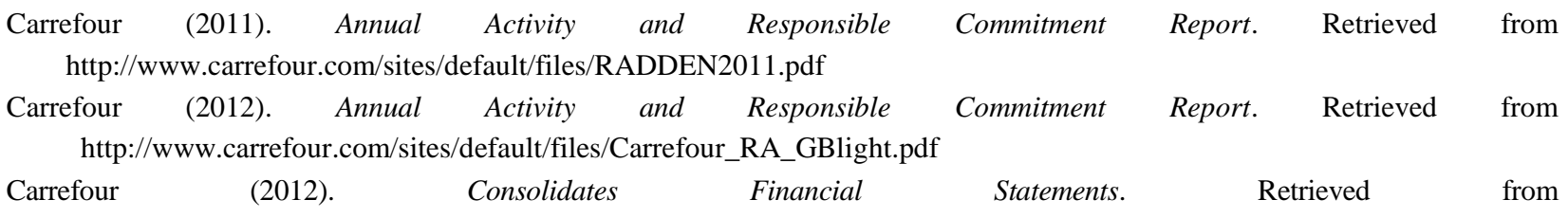
http://www.ecobook.eu/carrefour/2013/dr2012en/DREN-2012.pdf

Carroll, A. B., \& Shabana, K. M. (2010). The business case for corporate social responsibility: A review of concepts, research and practice. International Journal of Management Review, 12(1), 85-105. 
Chernev, A. (2003). When more is less and less is more: The role of ideal point of availability and assortment in consumer choice. Journal of Consumer Research, 30, 170-183.

Costa, R., \& Menichini, T. (2013). A multidimensional approach for CSR assessment: The importance of the stakeholder perception. Expert Systems with Applications, 40(1), 150-161.

Danese, P., Romano, P., \& Formentini, M. (2013). The impact of supply chain integration on responsiveness: The moderating effect of using an international supplier network. Transportation Research Part E: Logistics and Transportation Review, 49(1), 125-140.

Deloitte (2013). Os Poderosos do Varejo Global. Retrieved from http://www.deloitte.com/view/pt_BR/br/index.htm

Doppelt, B. (2010). Leading change toward sustainability: A change management guide for business, government and civil society (2nd ed.). Sheffield: Greenleaf.

European Comission. (2011). European Comission Report (COM(2011)774). Retrieved from http://eur-lex.europa.eu/legal-content/EN/TXT/?uri=CELEX:52011DC0681

Fiala, P. (2005). Information sharing in supply chains. Omega, 33(5), 419-423.

Ghisi, F. A., De Camargo, S. H. C. R. V., \& Martinelli, D. P. (2003). Supermarket shopping networks of small and medium: A multicase study in the state of São Paulo. São Paulo: Competitive Retail.

Gibbon, P., Bair, J., \& Ponte, S. (2008). Governing global value chains: An introduction. Economy and Society, 37(3), 315-338.

Gpari (2013). Controle Acionário do grupo Pão-de-Açúcar. Retrieved from http://www.gpari.com.br/grupopaodeacucar/web/conteudo_pt.asp?idioma=0\&conta=28\&tipo=29897

Groupe Casino (2011). Annual and Corporate Social Responsibility Performance Report. Retrieved from http://www.groupecasino.fr/IMG/pdf/RA2011-EN.pdf

Groupe Casino (2012). Annual and Corporate Social Responsibility Performance Report. Retrieved from http://www.groupe-casino.fr/en/Download-the-2012-Annual.html

$\begin{array}{llllll}\text { Groupe } & \text { Casino } & \text { (2012). Registration Rocument } & \text { Report. } & \text { Retrieved }\end{array}$ http://www.groupecasino.fr/IMG/pdf/Casino_2012_Registration_Document.pdf

Hauser, J., Tellis, G., \& Griffin, A. (2006). Research on innovation: A review and agenda for marketing science. Marketing Science, 25(6), 687-717.

Hitt, M. A ., Ireland, R. D ., \& Hoskisoon, R. (2003). Strategic management. São Paulo: A pioneer Thomson Learning.

Brazilian Institute of Geography and Statistics. (2011). Annual Survey of Trade in Rio de Janeiro. Retrieved from http: //www.ibge.gov.br/home/estatística/economia/comercioeservico/pac/2009/pac2009.pdf

Keck, K. L., \& Samp, J. A. (2007). The dynamic nature of goals and message production as revealed in a sequential analysis of conflict interactions. Human Communication Research, 33, 27-47.

Kim, S. H., \& Huarng, K. H. (2011). Winning strategies for innovation and high-technology products management. J Bus Res, 64(11), 1147-1150.

Knox, S., \& Maklan, S. (2004). Corporate social responsability: Moving beyond investment towards measuring outcomes. European Management Journal, 22(5), 508-516.

Liu, M., \& Wilson, S. R. (2011). The effects of interaction goals on negotiation tactics and outcomes: A dyad-level analysis across two cultures. Communication Research, 38, 248-277.

Luppe, M. R. (2010). Evidências da sofisticação do padrão dos domicílios brasileiros: uma análise de cestas de produtos de consumo doméstico. São Paulo: Universidade de São Paulo.

Marques, E. F., \& Noronha, A. B. (2001). Avaliação e dimensionamento da percepção de excelência de serviços no setor supermercadista: uma abordagem quantitativa. Varejocompetitivo, 5, 173-197.

Mishina, Y., Pollock, T. G., \& Porac, J. F. (2004). Are more resources always better for growth? Resource stickiness in market and product expansion. Strategic Management Journal, 25(12), 1179-1197.

Mogilner, C., Rudnick, T., \& Iyengar, S. S. (2008). The mere categorization effect: How the presence of categories increases choosers perceptions of assortment variety and outcome satisfaction. Journal of Consumer Research, 35(2), $202-215$.

Nielsen Company (2011). Global Private Label Report: The rise of the value conscious shopper. Retrieved from www.au.nielsen.com/site/documents/PrivateLabelGlobalReportMar2011.pdf

Nohria, N., \& Gulati, R. (1996). Is slack good or bad for innovation? Acad.Management, 39(5), 1245-1264.

Parisotto, I. R. S. (2005). Application of balanced scorecard on performance evaluation in supermarket (Dissertation). Retrieved from http://proxy.furb.br/tede/tde_busca/arquivo.php?codArquivo=436 
Pinto, C. D. (2007). Análise da concorrência no setor de supermercados de Salvador na perspectiva de uma política antitruste. Salvador: Universidade Salvado.

Porter, M. E. (2004). Estratégia Competitiva: técnicas para análise de indústrias e da concorrência (2nd ed.). Rio de Janeiro: Elsevier.

Ratchford, B. T. (1982). Cost benefit models for explaining consumer choice and information seeking behavior. Management Science, 28(2), 197-212.

Schawartz, B. (2000). Self-Determination: The tyrammy of freedom. American Psychologist, 55(1), 79-88.

Squire, B., Cousins, P. D., Lawson, B., \& Brown, S. (2009). The effect of supplier manufacturing capabilities on buyer responsiveness-The role of collaboration. International Journal of Operations \& Production Management, 29(8), $766-788$.

Veiga, J. E. (2010). Sustentabilidade: a legitimação de um novo valor. São Paulo: Senac.

Venkatraman, N., \& Henderson, J. C. (1998). Real strategies for virtual organizing. Sloan Management Review, 40(1), 33-48.

Walmart (2011). Walmart 2011 Annual Report. Retrieved from http://www.walmartstores.com/sites/annualreport/2011/

Walmart (2013). Walmart 2012 Annual Report. Retrieved http://www.walmartstores.com/sites/annual-report/2012/WalMart_AR.pdf

Wilson, S. R., \& Putnam, L. L. (1990). Interaction goals in negotiation. In J.A. Anderson (Ed.), Communication Yearbook 13 (pp. 374-406). Newbury Park, CA: Sage.

Woodside, A., Ko, E., \& Huan, T. C. (2012). A nova lógica na construção de teoria isomórfica de decisão realidades de gestão. Decision Management, 50(5), 765-777. 